\title{
Cattle rabies: the effect of clinical evolution, viral genetic lineage, and viral load on the severity of histological lesions ${ }^{1}$
}

\author{
Claudia S. Wisser ${ }^{2 *}$ (D) André Thaler Neto ${ }^{3}$, Helena B.C.R. Batista ${ }^{4}$, Enio Mori ${ }^{4}$, Maria \\ E.R. Chierato ${ }^{4}$, Marcélia E.S. Fernandes ${ }^{4}$ (i) and Sandra D. Traverso ${ }^{2}$
}

\begin{abstract}
Wisser C.S., Thaler Neto A., Bastista H.B.C.R., Mori E., Chierato M.E.R, Fernandes M.E.S. \& Traverso S.D. 2020. Cattle rabies: the effect of clinical evolution, viral genetic lineage, and viral load on the severity of histological lesions. Pesquisa Veterinária Brasileira 40(4):227-233. Centro de Ciências Agroveterinárias, Universidade do Estado de Santa Catarina, Av. Luiz de Camões 2090, Bairro Conta Dinheiro, Lages, SC 88520-000, Brazil. E-mail: claudiawisser@hotmail.com

Our objective was the characterization and staging of histological lesions in different anatomical sites of the central nervous system (CNS) of rabid cattle. The severity of the lesions was compared with the clinical stages of the disease, the variants of viral isolates, and with the load of virus. Thirty-one spontaneously affected rabid cattle the state of Santa Catarina underwent clinical follow-up and were eventually necropsied. CNS tissues were sampled and submitted to direct fluorescent antibody technique (DFAT), immunohistochemistry (IHC), routine histopathology with hematoxylin and eosin stain (HE), reverse transcriptase polymerase chain reaction (RT-PCR), and polymerase chain reaction in quantitative reverse transcriptase in real time (qRT-PCR). Affected cattle were allotted in four groups according to their clinical stage when euthanized: G1, euthanized while standing; G2, euthanized when in sternal recumbence; G3, euthanized when in lateral recumbence; and G4, affected cattle with natural death. In order to evaluate the degree of severity of the lesions and the presence of Negri bodies (NBs), the brain was sectioned at 9 sites. Additionally, spinal cord and trigeminal ganglion sections were examined. The intensity of the lesions was graded as either absent, mild, moderate, or marked, and the presence or absence of the NBs was noted. Histological lesions were characterized by lymphocytic and monocytic meningoencephalitis with NBs in 28 cases. In all analyzed groups, intensities of histological lesions ranging from mild to severe were observed. Brain regions with the highest inflammatory lesion intensity were the medulla at the level of obex, followed by the colliculus and thalamus. NBs were observed in a higher percentage in the cerebellum, followed by medulla at the obex level, striatum complex, and frontal telencephalon. The duration of the clinical course of the disease did not influence the intensity of the inflammatory lesion, but it did influence the presence of NBs, with a higher percentage of these inclusions in cattle that died naturally than in euthanized cattle. All isolated rhabdovirus included in this study were genetically compatible with samples from hematophagous bats Desmodus rotundus. The evaluation by qRT-PCR did not demonstrate a correlation between lesion intensity and the amount of virus.
\end{abstract}

INDEX TERMS: Cattle rabies, clinical course, virus, genetic lineage, histology, lesion severity, RT-PCR.

\footnotetext{
${ }^{1}$ Received on August 12, 2019.

Accepted for publication on. August 27, 2019

Part of the doctoral thesis of the first author.

${ }^{2}$ Laboratório de Patologia Animal, Departamento de Medicina Veterinária, Centro de Ciências Agroveterinárias (CAV), Universidade do Estado de Santa Catarina (UDESC), Avenida Luiz de Camões 2090, Bairro Conta Dinheiro, Lages, SC 88520-000, Brazil. *Corresponding author: claudiawisser@hotmail.com
}

\footnotetext{
${ }^{3}$ Departamento de Produção Animal e Alimentos, Centro de Ciências Agroveterinárias (CAV), Universidade do Estado de Santa Catarina (UDESC), Avenida Luiz de Camões 2090, Bairro Conta Dinheiro, Lages, SC 88520-000, Brazil.

${ }^{4}$ Instituto Pasteur de São Paulo, Avenida Paulista 393, Cerqueira César, São Paulo, SP 01311-000, Brazil.
} 
RESUMO.- [Raiva bovina: relação do curso clínico, da linhagem genética do vírus e carga viral com a intensidade de lesões histológicas.] Nosso objetivo foi a caracterização e estadiamento de lesões histológicas em diferentes locais anatômicos do sistema nervoso central (SNC) de bovinos raivosos. A gravidade das lesões foi comparada com os estágios clínicos da doença, as variantes dos isolados virais e com a quantidade de vírus. Trinta e um bovinos do estado de Santa Catarina, afetados naturalmente por raiva, foram acompanhados clinicalmente e, ao final, necropsiados. Os tecidos do SNC foram amostrados e submetidos a imunofluorescência direta, imunohistoquímica, histopatologia de rotina, reação em cadeia da polimerase via transcriptase reversa (RT-PCR) e reação em cadeia da polimerase em transcriptase reversa quantitativa em tempo real (qRT-PCR). Os bovinos afetados foram distribuídos em quatro grupos, de acordo com sua fase clínica: G1, eutanasiados quando ainda se mantinham em pé; G2, eutanasiados quando em decúbito esternal; G3, eutanasiados quando em decúbito lateral; e G4, bovinos afetados com morte natural. Para avaliar o grau de gravidade das lesões e a presença de corpúsculos de Negri (CNs), o cérebro foi seccionado em 9 locais. Além disso, seções da medula espinhal e do gânglio trigêmeo foram examinadas. A intensidade das lesões foi graduada como ausente, leve, moderada ou acentuada, e a presença ou ausência dos CNs foi anotada. Lesões histológicas foram caracterizadas por meningoencefalite linfocítica e monocítica com CNs em 28 casos. Em todos os grupos analisados foram observadas intensidades de lesões histológicas variando de leve a grave. As regiões cerebrais com maior intensidade de lesão inflamatória foram o bulbo no nível do obex, seguido do colículo e tálamo. CNs foram mais prevalentes no cerebelo, seguido pelo bulbo ao nível do óbex, corpo estriado e telencéfalo frontal. A duração do curso clínico da raiva não influenciou a intensidade da lesão inflamatória, mas influenciou a presença de CNs, com maior porcentagem dessas inclusões em bovinos que morreram naturalmente do que em bovinos sacrificados. Todos os isolados rabdovírus obtidos neste estudo eram geneticamente compatíveis com amostras provenientes de morcegos hematófagos Desmodus rotundus.

TERMOS DE INDEXAÇÃO: Raiva bovina, evolução clínica, linhagem genética, vírus, histologia, intensidade das lesões, RT-PCR, bovinos.

\section{INTRODUCTION}

Rabies is an infectious, notifiable disease that affects the central nervous system (CNS) of several species (Barros et al. 2006, Beigh et al. 2015, Faizee et al. 2012). It causes acute encephalomyelitis in all warm-blooded animals, including humans and many wild species, which can serve as reservoirs for the virus (Rupprecht \& Gibbons 2004).

The disease is caused by RNA viruses, belonging to the genus Lyssavirus of the family Rhabdoviridae (Buchen-Osmond 2003). Based on phylogenetic analysis, the genus Lyssavirus is currently divided into seven genotypes (Heaton et al. 1999). The classical rabies lyssavirus (RABV) and its strains are known worldwide as the cause of rabies in humans and animals (Paweska et al. 2006), and so far Genotype 1, is the only one isolated in the Americas (Schaefer et al. 2005)
The RABV circulates within two interrelated epidemiological cycles, the urban and the wild cycle (Escobar et al. 2013). In Brazil, rabies prevalence is maintained by the main reservoirs, the dog in the urban cycle and bats in the wild cycle (Dietzschold et al. 1988, Schaefer et al. 2005). Evaluation of isolates from different regions of Brazil has identified that most cattle samples are related to the rabies virus from hematophagous bats (Schaefer et al. 2005). The isolated variant of hematophagous bats (Desmodus rotundus) is important throughout Latin America not only due to economic livestock losses but also to the impact on public health by transmission to humans (Rupprecht et al. 2018). In 2007, six cases of human rabies were recorded in Brazil; all of which were caused by variant 3 of hematophagous bats (D. rotundus) (Brasil 2018).

A recent case of autochthonous human rabies has been reported from Santa Catarina and the last reported cases of human and canine rabies in this southern Brazilian State were diagnosed respectively in 1981 and 2016 (DIVE 2019). Cases of rabies in herbivores are frequently reported from Santa Catarina (CIDASC 2019) but, there are insufficient data informing about different viral variants circulating the State.

Nervous lesions are characterized by lymphocytic and monocytic infiltration in the perivascular spaces an meninges, gliosis, and neuronal degeneration and necrosis (Beck et al. 2017, Rupprecht et al. 2018). Characteristic eosinophilic inclusion bodies, the Negri bodies (NBs) may be present in the neuronal cytoplasm (Beck et al. 2017). It is estimated that in up to $30 \%$ of cases of rabies in cattle, NBs are not visible in routine histological staining (Barros et al. 2006).

The intensity of the lesions is quite variable (Summers et al. 1995). It is believed that several factors can influence the lesion intensity, such as the type and concentration of the virus (Fernandes \& Riet-Correa 2007), the incubation period, the duration of the clinical course of the disease, individual reaction of the infected animal (Germano et al. 1977). Although data linking clinical stages with histological changes in cattle are scarce, more severe lesions are often related to longer clinical courses (Langohr et al. 2003, Lima et al. 2005). Thus, it is believed that the severity of the lesions increases with disease progression (Langohr et al. 2003).

This study provides information on the characterization and staging of histological lesions in the different anatomical sites of the CNS in rabid, comparing with the clinical stages of the disease, the variants of circulating rabies virus in Santa Catarina.

\section{MATERIALS AND METHODS}

Tissue samples from central nervous system were obtained during necropsies of cattle with naturally acquired rabies after a follow-up of clinical cases in the State of Santa Catarina, southern Brazil. Affected cattle were euthanized only after the first positive diagnosis for rabies in a bovine involved in the outbreak. Affected cattle were allotted in four groups according to their clinical stage when euthanized: G1, euthanized while standing; G2, euthanized when in sternal recumbence; G3, euthanized when in lateral recumbence; and G4, affected cattle with natural death. The procedures for the current study were submitted to and approved by the Ethics Committee in Experimentation of the Agroveterinary Sciences Center (CETEA), of the State University of Santa Catarina, under protocol number 1.06.15.

Samples of the cerebellum, hippocampus, and thalamus were submitted to DFAT and IHC for confirmation of the diagnosis. A 
pool containing samples of cerebellum, brainstem and cortex was submitted to molecular characterization. The remained CNS tissue was preserved in $10 \%$ formaldehyde for histopathological evaluation.

DFAT was performed according technique previously described (Dean et al. 1996), for the use of antinucleocapsid polyclonal antiragic conjugate, produced at Instituto Pasteur of São Paulo/SP. The IHC was applied in the samples according to a protocol adapted from Pedroso et al. (2008) using Chemicon \#5199 polyclonal antirabies antibody.

For histological evaluation, the following portions were sectioned: the trigeminal ganglion, medulla at the level of the obex, cerebellum, rostral colliculus, frontal telencephalon, corpus striatum, parietal telencephalon, thalamus, temporal telencephalon, hippocampus, and cervical spinal cord. Hematoxylin and eosin (HE) stained sections were evaluated for the intensity of inflammatory lesions and classified as: (0) without alterations, (1) mild perivascular mononuclear infiltrate with up to two layers, and mild gliosis, (2) moderate perivascular mononuclear infiltrate with 3-4 cell layers and moderate gliosis, (3) marked perivascular mononuclear inflammation with 3-4 cell layers and marked gliosis or more than 4 layers of perivascular inflammatory cells. All regions were also evaluated for the presence of NBs.

Table 1. Severity of the histological lesions, by brain area, in the different groups of clinical evolution

\begin{tabular}{|c|c|c|c|c|c|c|c|c|c|c|c|c|c|}
\hline \multirow{2}{*}{ Bov } & \multirow{2}{*}{ Group } & \multirow{2}{*}{$\begin{array}{l}\text { Day of } \\
\text { death }\end{array}$} & \multicolumn{11}{|c|}{ Severity of inflammation in each region } \\
\hline & & & ME & TR & $\mathrm{OB}$ & $\mathrm{CR}$ & $\mathrm{CO}$ & $\mathrm{TF}$ & $\mathrm{CE}$ & $\mathrm{TP}$ & $\mathrm{TA}$ & TT & $\mathrm{HI}$ \\
\hline 1 & G1 & 4 & 2 & 3 & 3 & 1 & 3 & 0 & 3 & 1 & 3 & 1 & 1 \\
\hline 2 & G1 & 3 & 3 & 1 & 3 & 1 & 3 & 1 & 0 & 0 & 2 & 0 & 0 \\
\hline 3 & G1 & 3 & NA & 3 & 2 & 1 & 3 & 1 & 2 & 1 & 2 & 0 & 1 \\
\hline 4 & G1 & 4 & 1 & NA & 2 & 1 & 2 & 1 & 2 & 2 & 1 & 1 & 1 \\
\hline 5 & G1 & 5 & 2 & 1 & 3 & 3 & 2 & 2 & 3 & 2 & 2 & 1 & 2 \\
\hline 6 & G1 & 2 & 0 & 0 & 2 & 1 & 2 & 1 & 1 & 1 & 3 & 1 & 1 \\
\hline 7 & G2 & 6 & 0 & NA & 1 & 0 & 1 & 1 & 0 & 0 & 1 & 0 & 0 \\
\hline 8 & G2 & 5 & 1 & 1 & 0 & 0 & 0 & 0 & 0 & 0 & 1 & 0 & 0 \\
\hline 9 & G2 & 6 & NA & NA & 1 & 1 & 2 & 1 & 1 & 1 & 2 & 0 & 0 \\
\hline 10 & G2 & 2 & 2 & 2 & 2 & 2 & 1 & 0 & 1 & 1 & 1 & 1 & 0 \\
\hline 11 & G2 & 4 & 1 & NA & 2 & 1 & 2 & NA & NA & 1 & 1 & 0 & 1 \\
\hline 12 & G2 & 5 & 1 & 1 & 2 & 1 & 2 & 0 & 1 & 0 & 2 & 1 & 1 \\
\hline 13 & G3 & 8 & 1 & 1 & 2 & 2 & 2 & 1 & 1 & 1 & 2 & NA & 1 \\
\hline 14 & G3 & 8 & 1 & NA & 3 & 2 & 2 & 2 & 2 & 1 & 2 & 2 & 2 \\
\hline 15 & G3 & 8 & NA & NA & 1 & 1 & 1 & 0 & 0 & 0 & 1 & 0 & 0 \\
\hline 16 & G3 & 3 & NA & NA & 2 & 1 & 2 & NA & 1 & 1 & 1 & 0 & 1 \\
\hline 17 & G3 & 5 & 1 & NA & 2 & 1 & 2 & 1 & 2 & 1 & 2 & 1 & 1 \\
\hline 18 & G3 & 7 & NA & 2 & 2 & 1 & 2 & NA & 1 & 0 & 1 & 0 & 0 \\
\hline 19 & G3 & 7 & NA & 2 & 3 & 1 & 1 & 0 & 1 & 0 & 1 & 0 & 1 \\
\hline 20 & G3 & 4 & NA & 1 & 2 & 1 & 1 & 0 & 1 & 0 & 1 & 0 & 0 \\
\hline 21 & G3 & 5 & 0 & NA & 2 & 1 & 3 & 2 & 2 & 1 & 2 & 1 & 1 \\
\hline 22 & G3 & 2 & 3 & 2 & 3 & 3 & 2 & 1 & 1 & 1 & 3 & 0 & 0 \\
\hline 23 & G3 & 5 & 2 & NA & 3 & 2 & 2 & 2 & 2 & 2 & 2 & 2 & 2 \\
\hline 24 & G3 & 3 & 2 & NA & 3 & 3 & 3 & 2 & 2 & 1 & 2 & 1 & 2 \\
\hline 25 & G3 & 7 & 3 & 1 & 3 & 2 & 3 & 2 & 2 & 1 & 3 & 1 & 2 \\
\hline 26 & G3 & 4 & 1 & 1 & 3 & 3 & 2 & 2 & 2 & 1 & 3 & 0 & 2 \\
\hline 27 & G3 & 4 & 2 & 1 & 2 & 1 & 2 & 0 & 2 & 1 & 1 & 0 & 1 \\
\hline 28 & G4 & 5 & 1 & 3 & 3 & 1 & 3 & 1 & 1 & 1 & 2 & 0 & 1 \\
\hline 29 & G4 & 6 & 2 & NA & 3 & 1 & 2 & 1 & 2 & 1 & 3 & 1 & 0 \\
\hline 30 & G4 & 3 & NA & NA & 3 & 2 & 3 & 2 & 3 & 2 & 3 & 1 & 2 \\
\hline 31 & G4 & 3 & 2 & NA & 3 & 2 & 3 & 3 & 3 & 2 & 3 & 2 & 3 \\
\hline
\end{tabular}

G1 = Cattle euthanized while standing, G2 = euthanized when in sternal recumbence, G3 = euthanized when in lateral recumbence, G4 = affected cattle with natural death, $\mathrm{NA}=$ unrecorded region, $0=$ absence of lesions, $1=$ mild inflammation, $2=$ moderate inflammation, $3=$ marked inflammation, $\mathrm{ME}=$ spinal cord, $\mathrm{TR}=$ ganglion trigeminal, $\mathrm{OB}=$ medulla at the obex level, $\mathrm{CR}=$ cerebellum, $\mathrm{CO}=$ rostral colliculus, $\mathrm{TF}=$ frontal telencephalon, $\mathrm{CE}=\mathrm{corpus}$ striatum, $\mathrm{TP}=$ parietal telencephalon, $\mathrm{TA}=$ thalamus, $\mathrm{TT}=$ temporal telencephalon, $\mathrm{HI}=$ hippocampus . 
For molecular characterization, RT-PCR followed by genetic sequencing was performed, using a pool containing samples of cerebellum, brainstem, and cortex. The total RNA from each of the samples was extracted using TRIzol Reagent (Invitrogen ${ }^{\mathrm{TM}}$ ). For the reverse transcription, $5 \mu \mathrm{l}$ of the RNA extracted from each sample was utilized, 21G (sense) (5'-ATGTAACACCTCTACAATG-3') and 304 (antisense) primers (5'-TTDACGAAGATCTTGCTCAT-3') directed to the RABV nucleoprotein gene and the kit Superscript ${ }^{\mathrm{TM}}$ II Reverse Transcriptase (Invitrogen ${ }^{\mathrm{TM}}$ ). PCR primers 21G, 304 and the recombinant Taq DNA polymerase kit (Invitrogen ${ }^{\mathrm{TM}}$ ) were used. Both RNA extraction and RT-PCR were performed according to the manufacturer's instructions. For each amplified sample, the genetic sequencing with each primer previously described was separately performed using $4 \mu \mathrm{l}$ of BigDye 3.1 (Applied Biosystems), 3.2pmol of each primer, 30-50ng of target DNA and water DNAse/RNAse free qsp for a final reaction of $10 \mu$. The product of this reaction was further purified with Sephadex (GE Healthcare ${ }^{\mathrm{TM}}$ ) in a 96-well plate following the manufacturer's instructions. Subsequently, the plate was taken to the ABI-3130 automatic gene analyzer (Applied Biosystems $^{\mathrm{TM}}$ ) to obtain the electropherograms of the sequences of DNA. The nucleotides of the electropherograms were checked manually with the program Chromas v.2.23 ( ${ }^{\circledR} 1998-2002$ Technelysiumm Pty LTD) and the final sequence obtained with the Cap-Contig application of the BIOEDIT v.5.0.9 (Hall 1999), which was then compared with others retrieved by BLASTn ${ }^{5}$ to obtain the identities of the genetic lines of the samples. The sequences were aligned by the CLUSTAL/W method, for which the BIOEDIT program was used, v.5.0.9. Phylogenetic trees were obtained using the Neighbor-Joining algorithm and Kimura-2-parameter evolutionary model, with 1000 bootstrap repetitions with the MEGA program (Kumar et al. 2001).

The qPCR was performed using the SyBR Green I system and the antisense primers 304 and sense 504 (5'-TATACTCGAATCATGATGAATGGAGGTCGACT-3'). For the realtime RT-PCR, $2 \mu \mathrm{L}$ per sample was used, plus $9 \mu \mathrm{L}$ of free nuclease water, $12.5 \mu \mathrm{L}$ of $2 \mathrm{X}$ Power SYBR ${ }^{\circledR}$ Green PCR Master Mix (Applied Biosystems) and $0.75 \mu \mathrm{L}$ of each primer and antisense (504 and $304)$ at $10 \mu \mathrm{M}$. Each sample was analyzed in duplicate using MicroAmp0ptical 96-well Reaction Plate in the Applied Biosystems 7500 Real-Time PCR System apparatus. The results were analyzed using the 7500 Software v.2.0.5. The specificity of the reaction was verified by the analysis of the dissociation or melting curve. Samples with quantification cycle $(\mathrm{Cq})<35$ were considered positive by RTqPCR. When samples showed $\mathrm{Cq}>35$ or $\mathrm{Cq}<40$, they were considered as inconclusive results, requiring 1\% agarose gel electrophoresis. When the samples presented $\mathrm{Cq}>40$, they were considered negative.

The data obtained in the histological evaluation were subjected to statistical analysis, with a completely randomized experimental design. The data of the quantitative variables (intensity of the inflammatory lesion and NBs presence) were subjected to the analysis of variance using the mixed procedure of the statistical package SAS. The intensity data were analyzed as repeated measures in the space for each animal (random variable) The statistical model includes the effects of the group with the region of the nervous system and the interaction between these variables. The Kolmogorov-Smirnov test evaluated the normality of the residues, and the means were compared by the Tukey test at the $5 \%$ level of statistical significance.

$\overline{{ }^{5} \text { Available at <http://www.ncbi.nlm.nih.gov/BLAST> }}$

\section{RESULTS}

All samples were confirmed as rabies positive through IHC and DFAT. Histological lesions were characterized by lymphocytic and macrophagic meningoencephalitis associated with gliosis, with intensities ranging from mild to severe and NBs present in most cases. Table 1 and 2 describe the data regarding the group and day of clinical evolution of each cattle, as well as the intensity of inflammatory lesions and the presence of inclusions in each anatomic CNS site

The encephalic regions with the highest intensity of inflammatory lesions were the obex, followed by the colliculus, thalamus, and trigeminal ganglion, with no statistical difference between them ( $p>0.005)$. The average intensity of actions in the 11 regions evaluated can be observed in Table 3. NBs were observed in 28 of the 31 cattle (90.3\%). The cerebellum was the region with the highest percentage of inclusions, followed by the obex, corpus striatum and frontal telencephalon, with no statistical difference between them (Table 3).

Table 4 shows the relationship between the clinical evolution of the disease, the intensity of the histological lesion and the presence of NBs. It was observed that the clinical evolution of rabies had no effect on the intensity of the inflammatory lesion, as the difference was not statistically significant $(\mathrm{P}>0.05)$ between cattle euthanized in standing (G1) and those naturally dead (G4). There was also no statistically significant difference between cattle euthanized in standing (G1) and those euthanized in lateral recumbency (G3). On the other hand, there was a correlation with the presence of NBs, since animals with spontaneous death had a higher percentage of inclusions, with a statistically significant difference in relation to those that were euthanized for examination.

The comparative analysis between the sequences generated and the sequences retrieved from GenBank showed that all the isolated RABV samples included in the present study show a genetic lineage characteristic of hematophagous bats Desmodus rotundus. Of the 31 samples collected, nine amplicated. The highest viral load was not found not to be related to a greater mean intensity of the lesion, nor to differences in clinical evolution. The ratio of the cycles threshold (CT) in RT-PCR with clinical evolution and lesion intensity can be observed in Table 5. For example, Cattle BOV2 and BOV26, with higher viral load, had lesion intensity similar to BOV3 and BOV13, with a lower virus replication rate.

\section{DISCUSSION}

The intensity of the histological lesions of rabies can be quite variable (Summers et al. 1995) and it is believed that the stage and course of the disease, together with the viral strain and load, can influence both the onset of inflammatory lesions and of the development of NBs (Fernandes \& Riet-Correa 2007).

The most prominent inflammatory lesions in this study were observed in the medulla, colliculus and thalamus which is similar to the distribution described by others (Langohr et al. 2003) and are possibly related to the characteristics of the route of viral infection, since the virus spreads from the site of replication by rapid retrograde axonal transport (Wang et al. 2013) reaching first the trunk (spinal cord) and then the brain. More pronounced inflammation in the brainstem could prevent viral spread to the cerebral hemispheres (Shuangshoti et al. 2013). 
Table 2. Presence of Negri bodies (NBs), by brain area, in the different groups of clinical evolution, in the different animals

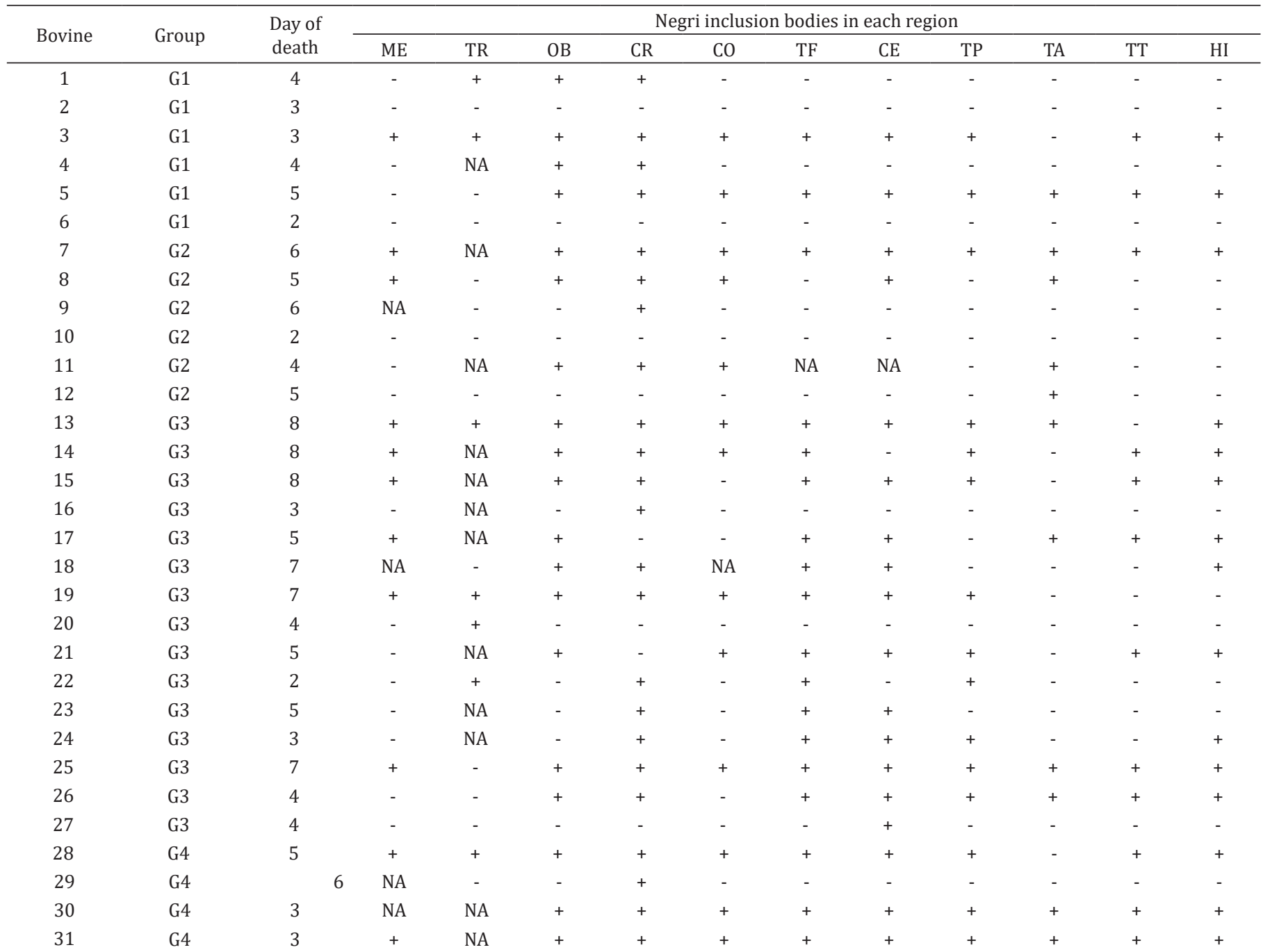

G1 = Cattle euthanized while standing, G2 = euthanized when in sternal recumbence, G3 = euthanized when in lateral recumbence, G4 = affected cattle with natural death, $\mathrm{NA}=$ unrecorded region; $(+)$ presence of Negri inclusions, $(-)$ no inclusion of Negri; $\mathrm{ME}=$ spinal cord, $\mathrm{TR}=$ ganglion trigeminal, $\mathrm{OB}=$ medulla at the obex level, $\mathrm{CR}=$ cerebellum, $\mathrm{CO}=$ rostral colliculus, $\mathrm{TF}=$ frontal telencephalon, $\mathrm{CE}=$ corpus striatum, $\mathrm{TP}=$ parietal telencephalon, $\mathrm{TA}=$ thalamus, $\mathrm{TT}$ $=$ temporal telencephalon, $\mathrm{HI}=$ hippocampus.

Table 3. Estimation of lesion intensity and percentage of Negri inclusion bodies in the different encephalic regions

\begin{tabular}{ccc}
\hline Region & Intensity of lesion & $\begin{array}{c}\text { Percentage of } \\
\text { inclusions of Negri }\end{array}$ \\
\hline Obex & $2.3083^{\mathrm{a}}$ & $61.29^{\mathrm{ab}}$ \\
Colliculus & $2.1458^{\mathrm{a}}$ & $43.33^{\mathrm{b}}$ \\
Thalamus & $2.0125^{\mathrm{a}}$ & $35.48^{\mathrm{b}}$ \\
Trigeminal & $1.9089^{\mathrm{ab}}$ & $36.84^{\mathrm{b}}$ \\
Striated complex & $1.5502^{\mathrm{bc}}$ & $60.00^{\mathrm{ab}}$ \\
Spinal cord & $1.4569^{\mathrm{bc}}$ & $40.74^{\mathrm{b}}$ \\
Cerebellum & $1.3333^{\mathrm{cd}}$ & $74.19^{\mathrm{a}}$ \\
Frontal telencephalon & $1.0787^{\mathrm{de}}$ & $60.00^{\mathrm{ab}}$ \\
Parietal telencephalon & $0.9917^{\mathrm{e}}$ & $48.39^{\mathrm{b}}$ \\
Hippocampus & $0.9750^{\mathrm{e}}$ & $48.39^{\mathrm{b}}$ \\
Temporal telencephalon & $0.6421^{\mathrm{f}}$ & $38.71^{\mathrm{b}}$
\end{tabular}

$\overline{\mathrm{a}, \mathrm{b}, \mathrm{c}, \mathrm{d}, \mathrm{e}, \mathrm{f} \text { Averages followed }}$ by the same letter do not differ from each other $(\mathrm{P}>0.05)$ by the Tukey test.
Table 4. Effect of the clinical evolution of rabies in the presence of the Negri inclusion bodies and the severity of inflammatory lesion

\begin{tabular}{ccc}
\hline Group & $\begin{array}{c}\text { Percentage of inclusions } \\
\text { of Negri }\end{array}$ & Intensity of lesion \\
\hline G1 & $36.92^{\mathrm{c}}$ & $1.81^{\mathrm{ab}}$ \\
G2 & $36.07^{\mathrm{c}}$ & $1.06^{\mathrm{c}}$ \\
G3 & $55.13^{\mathrm{b}}$ & $1.66^{\mathrm{b}}$ \\
G4 & $75^{\mathrm{a}}$ & $2.3^{\mathrm{a}}$
\end{tabular}

G1 = Cattle euthanized while standing, G2 = euthanized when in sternal recumbence, G3 = euthanized when in lateral recumbence, G4 = affected cattle with natural death; ${ }^{\mathrm{a}, \mathrm{b}, \mathrm{c}}$ Averages followed by the same letter do not differ from each other $(\mathrm{P}>0.05)$ by the Tukey test. 
However, when it comes to the clinical course of the disease, previous studies report cattle with a 3-4 days of evolution without histological lesions in the CNS (Marcolongo-Pereira et al. 2011) and suggest that more severe lesions are observed in cases with more prolonged evolution (Lima et al. 2005). In the current study, even cattle that were euthanized in the early stages of the disease, with 2-3 days of evolution and were still able to stand, presented marked histological lesions in some encephalic anatomical sites. In addition, it was observed that even cattle that died after a clinical course of 7-8 days or longer had similar or even milder lesions than those that were euthanized in the early stages. These data suggest that clinical evolution cannot be considered as the only determinant factor for the severity of inflammatory histological lesions.

Regarding NBs, this study showed that their presence was influenced by the duration of the clinical course. Out of the 31 cases analyzed, only three samples did not present NBs; those were from cattle euthanized in the early stages of the disease. According to Summers et al. (1995), the premature euthanasia of affected animals can result in cases with absence of NBs. According to Langohr et al. (2003) inclusions are most frequently detected in animals which survived for more than 4 days after the onset of clinical signs. This was also observed when we analyzed each case individually, since cattle without NBs were euthanized up to 3 days after the onset of clinical signs.

However, controversial data may be inferred if one considers that two cattle that died spontaneously (without euthanasia) in the present study had a very acute clinical course (up to 3 days) and yet presented inclusion bodies in all the analyzed areas of the encephalon, indicating that a short clinical course does not necessarily equate with lack of development of NBs. Moreover, a bovine that died after a clinical course of 6 days in the current study had NBs only in the cerebellum. NBs developed more often in the cerebellum of cattle from the current study corroborating the findings from others (Langohr et al. 2003, Silva et al. 2010). However, in one bovine NBs were found only in the trigeminal ganglion. This finding indicates that a more careful analysis of other areas of the nervous system should be made when there is no NBs found in the cerebellum, cortex, or hippocampus. A higher frequency of NBs were demonstrated in portions of

Table 5. Relationship among clinical evolution, inflammatory lesion and viral load of cattle in different groups

\begin{tabular}{ccccc}
\hline Bovine & Groups & $\begin{array}{c}\text { Day of } \\
\text { death }\end{array}$ & $\begin{array}{c}\text { Mean of } \\
\text { inflammatory lesion }\end{array}$ & CT-qRT-PCR \\
\hline 2 & G1 & 3 & 1.27 & 28.05 \\
3 & G1 & 3 & 1.6 & 13.074 \\
9 & G2 & 6 & 1 & 19.431 \\
13 & G3 & 8 & 1.4 & 18.29 \\
14 & G3 & 8 & 1.9 & 19.092 \\
23 & G3 & 5 & 2.1 & 22.7 \\
26 & G3 & 4 & 1.8 & 32,396 \\
29 & G4 & 6 & 1.6 & 22.41 \\
31 & G4 & 3 & 2.6 & 21.348
\end{tabular}

G1 = Cattle in standing, G2 = sternal recumbency, G3 = lateral recumbency, G4 = natural death. the spinal cord of horses when compared to other regions (Bassuino et al. 2016) concluding that the analysis of this portion of the CNS will increase the chances of establishing a rabies diagnosis.

According to Maxie \& Youssef (2006), NBs tend to be scarcer win sites where the inflammation is more severe. In this study, no relationship was established between NBs the intensity of the inflammatory infiltrate, as was previously observed (Langohr et al. 2003, Beck et al. 2017), since the region with the more severe inflammatory lesions, the medulla, was also the second most likely region to find NBs. The strain or type of virus is another factor that has been shown to influence the histological changes of rabies (Fernandes \& Riet-Correa 2007). The phylogenetic analysis of the samples obtained from cattle in the State of Santa Catarina were all identified as genetic lineage of hematophagous bats Desmodus rotundus (1B). Thus, the same strain presented lesions of varying intensity suggesting that lineage alone is not a determinant factor for the severity of the inflammatory histological lesions. Likewise, the evaluation of qRT-PCR did not show a relationship of lesion intensity with a greater viral load. This corroborates the findings of Appolinário et al. (2015) who observed that there was no relation of replication with different clinical presentations. According to Zhao et al. (2009) the difference in pathogenicity would be related to longer duration of cytokine and chemokine expression than to the effects of viral replication.

\section{CONCLUSIONS}

The duration of clinical course of rabies in cattle does not significantly affect the intensity of the inflammatory lesions in the different areas of the brain, but it does influence the development of the NBs, and there is a greater tendency to find NBs in rabid cattle that die spontaneously cattle when compared to those the were euthanized.

This study's viral evaluation indicated that for cattle infected with the genetic strain Desmodus rotundus (1B), variation in viral loads did not directly affect the intensity of the histological lesions.

Acknowledgments.- This study was financed in part by the "Coordenação de Aperfeiçoamento de Pessoal de Nível Superior" (CAPES), Brazil, Finance Code 001. The authors are also indebt to the "Fundação para o Apoio à Pesquisa e Inovação do Estado de Santa Catarina” (FAPESC), for funding the research.

Declaration of conflict of interest.- The authors have no conflict of interest.

\section{REFERENCES}

Appolinário C., Allendorf S.D., Vicente A.F., Ribeiro B.D., Fonseca C.R., Antunes J.M., Peres M.G., Kotait I., Carrieri M.L. \& Megid J. 2015. Fluorescent antibody test, quantitative polymerase chain reaction pattern and clinical aspects of rabies virus strains isolated from main reservoirs in Brazil. Braz. J. Infect. Dis. 19(5):479-485. <http://dx.doi.org/10.1016/j.bjid.2015.06.012> <PMid:26303004>

Barros C.S.L., Driemeier D., Dutra I.S. \& Lemos R.A.A. 2006. Doenças do Sistema Nervoso de Bovinos no Brasil. Vallée, São Paulo, p.21-28.

Bassuino D.M., Konradt G., Cruz R.A.S., Silva G.S., Gomes D.C., Pavarini S.P. \& Driemeier D. 2016. Characterization of spinal cord lesions in cattle and horses with rabies: the importance of correct sampling. J. Vet. Diagn. Invest. 28(4):455-460. <http://dx.doi.org/10.1177/1040638716647992> <PMid:27240569> 
Beck S., Gunawardena P., Horton D.L., Hicks D.J., Marston D.A., Ortiz-Pelaez A., Fooks A.R. \& Núñez A. 2017. Pathobiological investigation of naturally infected canine rabies cases from Sri Lanka. BMC Vet. Res. 13(1):99. <http://dx.doi.org/10.1186/s12917-017-1024-5>

Beigh A.B., Sandhu B.S., Singh C.K., Gupta K. \& Sood N.K. 2015. Comparative evaluation of clinicopathological, immunohistochemical, and immunofluorescent techniques for diagnosis of rabies in animals. Comp. Clin. Pathol. 24(5):11771184. <http://dx.doi.org/10.1007/s00580-014-2057-9>

Brasil 2018. Raiva: situação epidemiológica, 2018. Secretaria de Defesa Agropecuária, Ministério de Agricultura, Pecuária e Abastecimento, Brasília, DF.

Buchen-Osmond C. 2003. The Universal Virus Database ICTVDB. Computing Sci. Eng. 5:16-25.

CIDASC 2019. Informes Epidemiológicos. Defesa Sanitária Animal, Companhia Integrada de Desenvolvimento Agrícola de Santa Catarina, Florianópolis, SC. Available at <http://www.cidasc.sc.gov.br/defesasanitariaanimal/ informes-epidemiologicos/> Accessed on Jun. 16, 2019.

Dean D.J., Abelseth M.K. \& Atanasiu P. 1996. The fluorescent antibody test, p.88-93. In: Meslin F.X., Kaplan M.M. \& Koprowski H. (Eds), Laboratory Techniques in Rabies. Vol.1. 4th ed. World Health Organization, Geneva.

Dietzschold B., Rupprecht C.E., Tollis M., Lafon M., Mattei J., Wiktor T.J. \& Koprowski H. 1988. Antigenic diversity of glycoprotein and nucleocapsid proteins of rabies and rabies related viruses: implications for epidemiology and control of rabies. Rev. Infect. Dis. 10(supl.4):785-798. <http://dx.doi. org/10.1093/clinids/10.supplement_4.s785> <PMid:3206089>

DIVE 2019. Diretoria de Vigilância Epidemiológica, Florianópolis, SC. Available at <http://www.dive.sc.gov.br/index.php/arquivo-noticias/865-santacatarina-registra-primeiro-caso-de-raiva-humana-em-38-anos> Accessed on Jun. 16, 2019.

Escobar L.E., Peterson A.T., Favi M., Yung V., Pons D.J. \& Medina-Vogel G. 2013. Ecology and geography of transmission of two bat-borne rabies lineages in Chile. PLOS Neglected Trop. Dis. 7(12):e2577.<http://dx.doi. org/10.1371/journal.pntd.0002577><PMid:24349592>

Faizee N., Hailat N.Q., Ababneh M.M.K., Hananeh W.M. \& Muhaidat A. 2012. Pathological, immunological and molecular diagnosis of rabies in clinically suspected animals of different species using four detection techniques in Jordan. Transbound. Emerg. Dis. 59(2):154-164. <http://dx.doi. org/10.1111/j.1865-1682.2011.01255.x><PMid:22390575>

Fernandes C.G. \& Riet-Correa F. 2007. Raiva, p.184-198. In: Riet-Correa F., Schild A.L., Lemos R.A.A. \& Borges J.R.J. (Eds), Doenças dos Ruminantes e Equídeos. Vol.1. 3a ed. Pallotti, Santa Maria, RS.

Germano P.M.L., Miguel O., Chamelet E.L.B. \& Morita L.T.M.S. 1977. Estudo comparativo entre as técnicas de coloração de Sellers, imunofluorescência direta e inoculação em camundongos, aplicadas ao diagnóstico laboratorial da raiva canina. Revta Faculdade Med. Vet. Zootec. USP 14(1):133-141. <http://dx.doi.org/10.11606/issn.2318-3659.v14i1p133-141>

Hall T.A. 1999. BioEdit: a user-friendly biological sequence alignment editor and analysis program for windows 95/98/NT. Nucleic Acids Symp. Ser., Oxford, 41:95-98. <http://dx.doi.org/10.14601/Phytopathol_Mediterr14998u1.29>

Heaton P.R., Mcelhinney L.M. \& Lowings J.P. 1999. Detection and identification of rabies and rabies related viruses using rapid - cycle PCR. J. Virol. Methods 81(1/2):63-69. <http://dx.doi.org/10.1016/s0166-0934(99)00060-9> $<$ PMid:10488762>

Kumar A., Roach C., Hirsh I.S., Turley S., Walque S., Michels P.A. \& Hol W.G. 2001. An unexpected extended conformation for the third TPR motif of the peroxin PEX5 from Trypanosoma brucei. J. Mol. Biol. 307(1):271-282. <http://dx.doi.org/10.1006/jmbi.2000.4465><PMid:11243819>

Langohr I.M., Irigoyen L.F., Lemos R.A.A. \& Barros C.S.L. 2003. Aspectos epidemiológicos, clinicos e distribuição das lesões histologicas no encéfalo de bovinos com raiva. Ciência Rural 33(1):125-131. <http://dx.doi. org/10.1590/S0103-84782003000100020>

Lima E.F., Riet-Correa F., Castro R.S., Gomes A.A.B., \& Lima F.S. 2005. Sinais clinicos, distribuição das lesões no sistema nervoso e epidemiologia da raiva em herbivoros na região Nordeste do Brasil. Pesq. Vet. Bras. 25(4):250-264. <http://dx.doi.org/10.1590/S0100-736X2005000400011>

Marcolongo-Pereira C., Sallis E.S.V., Grecco F.B., Raffi M.B., Soares M.P. \& Schild A.L. 2011. Raiva em bovinos na Região Sul do Rio Grande do Sul: epidemiologia e diagnóstico imuno-histoquímico. Pesq. Vet. Bras. 31(4):331335. <http://dx.doi.org/10.1590/S0100-736X2011000400010>

Maxie M.G. \& Youssef S. 2006. The nervous system, p.267-439. In: Maxie M.G. (Ed.), Jubb, Kennedy and Palmer's Pathology of Domestic Animals, Vol.1. 4th ed. Academic Press, San Diego.

Paweska J.T., Blumberg L.H., Liebenberg C., Hewlett R.H., Grobbelaar A.A., Leman P.A., Croft J.E., Louis H., Nel L.H., Nutt L. \& Swanepoel R. 2006. Fatal human infection with rabies-related Duvenhage virus, South Africa. Emerg. Infect. Dis. 12(12):1965-1967. <http://dx.doi.org/10.3201/ eid1212.060764><PMid:17326954>

Pedroso P.M.O., Pescador C.A., Bandarra P.M., Raymundo D.L., Borba M.R., Wouters F., Bezerra-Júnior P.S. \& Driemeier D. 2008. Padronização da técnica de imuno-histoquimica para raiva em amostras de tecido do sistema nervoso central de bovinos fixadas em formol e emblocadas em parafina. Pesq. Vet. Bras. 28(12):627-632. <http://dx.doi.org/10.1590/ S0100-736X2008001200012>

Rupprecht C.E. \& Gibbons R.V. 2004. Clinical practice. Prophylaxis against rabies. New England J. Med. 351(25):2626-2635. <http://dx.doi.org/10.1056/ NEJMcp042140><PMid:15602023>

Rupprecht C.E., Fooks A.R. \& Abela-Ridder B. 2018. Laboratory Techniques in Rabies. Vol.1. 5th ed. World Health Organization, Geneva, p.64-65.

Schaefer R., Batista H.B.R., Franco A.C., Rijsewijk F.A.M. \& Roehe P.M. 2005. Studies on antigenic and genomic properties of Brazilian rabies virus isolates. Vet. Microbiol. 107(3/4):161-170.<http://dx.doi.org/10.1016/j. vetmic.2005.01.023><PMid:15863275>

Shuangshoti S., Thepa N., Phukpattaranont P., Jittmittraphap A., Intarut N., Tepsumethanon V., Wacharapluesadee S., Thorner P.S. \& Hemachudha T. 2013. Reduced viral burden in paralytic compared to furious canine rabies is associated with prominent inflammation at the brainstem level. BMC Vet. Res. 9(31):1-11.<http://dx.doi.org/10.1186/1746-6148-9-31> $<$ PMid:23410236>

Silva M. L. C. R., Riet-Correa F., Galiza G.J.N., Azevedo S.S., Afonso J.A.B. \& Gomes A.A.B. 2010. Distribuição do vírus rábico no sistema nervoso central em ruminantes naturalmente infectados. Pesq. Vet. Bras. 30(11):940-944. <http://dx.doi.org/10.1590/S0100-736X2010001100007>

Summers B.A., Cummings J. \& DeLahunta A. 1995. Veterinary Neuropathology. Mosby, Saint Louis. 527p.

Wang L., Cao Y., Tang Q. \& Liang G. 2013. Role of the blood-brain barrier in rabies virus infection and protection. Protein Cells 4(12):901-903.<http:// dx.doi.org/10.1007/s13238-013-3918-8><PMid: 24264143>

Zhao L., Toriumi H., Kuang Y., Chen H. \& Fu Z.F. 2009. The roles of chemokines in rabies virus infection: overexpression may not always be beneficial. J. Virol. 83(22):11808-11818. <http://dx.doi.org/10.1128/JVI.01346-09> <PMid:19740983> 